\title{
Storage Records and Servicing
}

By FRED L. DIMOCK

$\mathrm{O}^{\mathrm{un}}$ UR EXPERIENCE with storing books from the stacks of the general library at the University of Michigan goes back only to 1949. Prior to that time, our stacks had been overcrowded for years. Books were being shelved on the aisle floors and on wooden book-cases on the walls of the stacks. A second shelving arrangement existed on metal cases around the perimeter of some of the stack floors. Conditions for library users and library staff were indeed difficult. Similar conditions existed in most of the branch libraries housed in other buildings. Space for storage outside of the general library building became a reality in 1949 when the third floor of the stacks in the new business administration library was turned over to us. This floor accommodated forty thousand volumes. It was decided to select only sets of serials that had ceased publication and that as far as we knew were little used. This was advantageous as it was possible to make maximum use of the space available because it was not necessary to leave room for expansion.

Since this was our first experience at selecting material for storage, and even though we were fairly sure that the sets selected were not heavily used, it might happen that some of these items would have to be brought back because of unanticipated usage. It was at this time that our policy of not changing locations on the catalog cards was made. The initial expense of changing these records would have been great, and the possibility of having to relocate some books and once more change the records was a strong factor in setting the policy. There were also some special files which would require changing, such as the book-plate file, etc. Thus, the decision was made to keep a record of the stored volumes
Mr. Dimock is Head of the Circulation Department, University of Michigan Library. This paper was presented at the meeting of the ACRL University Libraries Section, Montreal, June 19, 1960.

only in the circulation department charge-out file. This was a simple and inexpensive means of control, costing only a few cents apiece for charging cards for the circulation charging file. The storage charge was made on a regular $3 \times 5$ charging card and interfiled in the circulation department file, which is a union file of all charges for stack books removed from their locations for circulation, binding, use in carrells, etc.

There were many things in favor of not changing catalog records at this time, other than the fact that our method was a simple and inexpensive means of control. The circulation desk was on the second floor close to the public catalog and centered between the only entrance and exit to the stacks. The stacks were open only to graduate students and faculty. All "not-on-shelf" reports for undergraduate students were automatically checked against the circulation file. Graduate students and faculty were accustomed to checking at this file for information on books they could not locate. Since the forty thousand volumes were represented by only fifteen hundred reference cards in the circulation file, there was no overcrowding. For the convenience of stack users manila envelopes were placed on the shelves stating that the set was in storage.

No more storage areas were provided until 1951, when we moved the entire $T$ classification of twenty-five thousand volumes housed in the general library to the basement of the school of education building. The storing of this entire classi- 
fication was not a hardship to library patrons since the engineering libraries with their extensive technical collections were centrally located on the main campus.

Our policy of not changing the location on the catalog cards for books sent to storage was continued. Since all the general library $T$ classification was involved, the only control record needed in our circulation charge-out file was a single charging card. To assist stack users the change was recorded also on all stack directions. This collection was later moved and integrated with those of the engineering libraries when the latter moved to quarters in the new undergraduate library building. The simplicity and minimum of record keeping for block storage cannot be better illustrated. When this entire $T$ collection of twentyfive thousand volumes was relocated in the engineering library only one card record, the one in the charging desk file, needed to be changed. The only other change was to alter the stack directory. The engineering library, however, has no catalog of this collection and Mr. Harrell, the engineering librarian, considers this a handicap in the servicing of this material.

In spite of the removal of the books to the two buildings mentioned it was not long before conditions in the stacks of the general library became as difficult as ever. Additional space could be provided on the central campus by adding to our present building or by providing another building. Because of the already overcrowded central campus, the university administration decided to erect a building especially designed for storage on the North Campus.

In preparation for the move to the new storage building, a committee of library staff members was formed to make recommendations concerning library storage records. The committee considered the experience that the catalog department had in 1953 when it transferred approximately three thousand volumes from the science library to the social science library. The report to the committee was that the time required to change the stamping on the catalog records was the equivalent of a full-time position for three months. Based on this previous experience, the catalog department estimated it would take five fulltime employees five years to complete the changing of records for transferring 300,000 volumes to the annex. The committee felt that this was too expensive and too slow and that a continuation of our system of simply putting cards in our main circulation file seemed the wise course to follow for many reasons. Basically, this system had a high degree of flexibility. If it were discovered that some of the stored items had heavier usage than anticipated, the items could easily be sent back with little expense to the library. However, if the catalog card had been changed in the public catalog, the official catalog, and the shelf list, a costly record-changing operation would follow when it was found necessary to return items to the stacks of the general library.

Also, the committee felt that the system would have the advantage of permitting rapid preparation of records. The committee's proposals were accepted and meant that the catalog department would not have to do anything with the changing of records at least for the time being and the work of record preparations would proceed under the direction of the circulation department.

Because of the considerable increase in the number of volumes and titles, our problem of preparing for the move and of record keeping was more complex. Fortunately, we had recently purchased a Photoclerk machine which proved to be of great assistance in the preparation of records. For adequate control it was decided to photograph three copies of the shelf list card for each title selected: one copy to be filed in the circulation chargeout file, the second for a shelf list record 
at the North Campus, and the third as an insurance record. The shelf list record and the insurance record are now filed in regular catalog drawers at the annex. Our charging records are filed, however, vertically, or the long way, which meant adapting the photographic record to the circulation department file. The essential information concerning annex location and call number were written on the reverse side of the photographic record, and it was filed vertically in our charge-out file.

On arrival at the new storage building, all materials were first inventoried, sized, then coded according to floor and drawer location, and finally shelved. The coding was marked on shelf list photographic records and on special labels which were then placed on the spine of each volume. As a result of the inventory, all shortages and missing items were recorded on the reverse side of the annex shelf list photographic records. As yet we have not been able to record this information on the insurance records; and until we have a final decision, based on a pilot project, from the catalog department on the changing of the location on catalog records, the charge in the circulation department file will not be annotated with the inventory results.

Divisional libraries with space problems also sent books to be stored. The records for materials sent to the annex from the divisional libraries were made and handled in the same manner. The only exception, of course, was that the photographic charges for the divisional library material were filed in the circulation file of the particular library involved and not in the circulation department file.

In February 1955 we began to move into the new building. The building was designed to hold approximately 400,000 volumes when completely equipped, and is situated on its site in such a way that another wing can be added when it becomes necessary. To date, only the first two floors have been completely equipped. The total capacity for these two floors was estimated to be 200,000 volumes. However, by using every bit of space, we estimate we have 220,000 volumes shelved on these two floors. On the third floor still another 20,000 volumes are shelved temporarily on conventional shelving. The building is equipped with Ames Stor-mor drawers, conventional shelving around the walls, and some special folio shelves. The first material to be transferred to this building was the original storage material housed in the business administration library. This was followed by additional materials which our selection department had decided could be stored.

Margaret Ayrault, head of the catalog department, has felt for some time that we are doing a disservice to our catalog users by not designating the location of storage books on the catalog cards. Agnes Tysse, head reference librarian, is in complete accord with Miss Ayrault.

Most recently the catalog department has begun a pilot project of changing the catalog records in the public catalog, the official catalog, and the shelf list for some selected storage materials. It was decided that nothing but monographic items would be handled. The results of this pilot project will give us an estimate of present cost in terms of time and money and should be of great assistance in helping us to arrive at a final policy. While we have adequate information control for the circulation staff on materials stored, the users of the public catalog do not immediately get this information. They go from the public cata$\log$ to the stacks. If what they want is not there, they may go down to the first floor to have the call number checked in the charge-out file, at which point they discover that what is wanted is in storage. We should soon arrive at a decision on the final policy for record keeping as the university library has just been allocated sufficient money to equip the third and 
fourth floors of the storage building. This means that we will have room for another 220,000 volumes. There are several courses of action concerning records that could be followed. We have discussed and discarded the idea of a separate shelf list at the public catalog only for storage materials for two reasons: one, it forces the public to look in two places for every title, and, two, it would be expensive to set up and to maintain especially if many corrections of call numbers, entries, etc., were necessary. We can add the location information to the catalog cards or we can continue to add charging cards for storage items to the circulation charging file. The present proportion of 75 per cent serials to 25 per cent monographs will probably be reversed; and because of the tremendous increase in the number of monographs to be stored, it may well be that it will be highly desirable to change the location information on the catalog records. Certainly a lot of time would be saved for those going to the stacks after using the public catalog. Another possible reason for changing the catalog record is that our charge-out file is now in the first floor corridor.

I should also like to point out that the photographic record we are using is not a permanent record due to the fact that it does not meet archival standards. As an experiment we have tried laminating both sides of some photographic slips and this will undoubtedly prolong the usefulness of the photographic record.

If it is decided to add the storage information to the catalog cards, this will eventually reduce the size of the circulation department charge-out file. We have approximately 175,000 cards in the charge-out file at this time. Of this amount, we estimate that there are thirty-five thousand cards for general library storage materials. Thus thirty-five thousand charges represent the 220,000 volumes from the general library. If it is decided to continue our present policy, the charging file will have to be enlarged as there is room for only a few thousand more cards. This will be especially true if, as expected, the proportion of 25 per cent monographs to 75 per cent serials is reversed because this would mean a great increase in the number of charges to be filed. My supervisory staff has considered the problems of a file almost twice as large as our present one and does not think it impractical or unworkable. Of course, if the selection department is able to select large areas of block storage, fewer charging cards would be needed as only one charging card is necessary for block storage.

\section{SERVICING}

Request for general library materials stored at the North Campus annex are serviced daily. All requests received before 1:00 P.M. are filled and sent to the circulation department and are ready for use by 4:30 P.M. the same day. Requests received after 1:00 P.M. are not serviced until the next day. The requests are telephoned to the annex, where the clerical assistant on duty checks the call numbers against the annex shelf list for the shelving code. If for any reason the materials requested are not available, the circulation department is notified immediately by phone to this effect. The North Campus is about two and one-half miles distant from the central campus, but the university provides a scheduled trucking service between the two places and library materials are delivered by this means. Heavy fiberboard tote boxes having a capacity of about thirty averagesized volumes are used to contain the items being sent.

All the divisional libraries having materials stored at the annex follow the same procedures just mentioned for servicing their books. One significant difference is that their materials are delivered to the general library where they are then put into tote boxes to be delivered the following morning to the particular library involved. The delay in the delivery 
of storage materials to the divisional libraries is due to the fact that the university library is just one unit being serviced by the university trucking service. Its schedules are highly complicated due to distance and number of units to be serviced. The one delivery a day from the North Campus to the general library comes late in the afternoon, while service from the general library to the divisionals is in the morning.

Those who go to the annex are permitted to service their own books providing they are in certain categories. For example, the perimeter shelves on the first three floors are occupied by various special collections and are kept in shelf list order. In shelving serials in the drawers, a policy of keeping sets together even though the size was not uniform was decided upon. This makes it very convenient for the library users who wish to use many volumes of a given title. The assistant on duty has only to locate the drawer for the user. Servicing of sized monographs stored in the drawers is done only by the assistant on duty as there has been no attempt to maintain a shelf list arrangement. It should be pointed out that the number of people going to the storage building to use the materials is small.

Should a decision be made to add the location to the catalog cards, the records for the material already stored will be changed first. We know from our experience that it will not be necessary to return many because of heavy usage. Actually, in four years only five hundred volumes have been returned; one hundred of these for the natural science li- brary and four hundred to the general library. The four hundred volumes returned to the general library were about 50-50 monographic and serial.

Monographs are returned to the general library if they are used five or more times within a year. It may well be that this arbitrary figure of usage will have to be revised upward when we have many more monographic materials stored. Serial sets are returned only if the whole set is used heavily. We can determine usage as all circulation records of storage items have been kept. Any requests from faculty or students for the permanent return of little used materials are referred to the selection department.

There has been a marked decline in the use of storage materials since the opening of the stacks of the general library to all students in July 1958. This decline amounted to 34 per cent in 1958-59 and it appears from the statistics of circulation available so far for 1959-60 that there will be a further reduction in the use of these materials. The opening of the stacks made it possible for the undergraduate to choose his own books from the stack shelves, and if he did not find the one he had in mind, usually he could locate an acceptable substitute. Prior to the opening of the stacks to undergraduates all "not-on-shelf" reports were automatically checked before being given to the student and if the item were in storage the student usually wanted it brought in. Opening of the stacks to all immediately reduced the number of requests for information on "not-on-shelf" items.

\section{Names Needed}

The Committee on Appointments and Nominations is looking for names of members of ACRL to be considered for appointment to one of the twelve committees of ACRL for the 1962-63 year. If you are interested in actively participating in our organization, or if you know of a fellow librarian who is qualified, forward his or her name and yours to Dale M. Bentz, Chairman, ACRL Committee on Appointments and Nominations, and Associate Director, State University of Iowa Libraries, Iowa City, Iowa. 